\title{
FACTORS AFFECTING COMPETITIVE RIVALRY OF RICE SHOP OWNERS: MULTIPLE REGRESSION ANALYSIS
}

\author{
MBM. Ismail \\ Senior Lecturer, Department of Management, Faculty of Management and Commerce \\ South Eastern University of Sri Lanka
}

\begin{abstract}
In today's globalised business World, business firms toil hard for to respond to business competition. Responding to business competition needs to know factors determining competition or rivalry. This study tries to determine factors affecting the competitive rivalry and to know the This study tries to determine factors affecting the competitive rivalry and to know the relationship among factors affecting competitive rivalry and competitive rivalry. Researcher selected 127 rice shop owners using a convenient sampling technique. Results showed that values of Cronbach alpha, items of factors are higher than 0.6. Values of KMO for items are higher than 0.5 . It is concluded that values of $R, R$ square and adjusted $R$ square that are greater than $0.953,0.908$ and 0.905 respectively showing that there is a high strength of association between among identified factors such as threats of new entry, power of suppliers, threats of substitutes, power of buyer and competitive rivalry of rice shop owners. F statistics confirm that all factors are related with competitive rivalry. But, T test confirm that all factors except threats of new entry are with competitive rivalry.
\end{abstract}

Keywords: Competitive Rivalry, Multiple Regression Analysis, Rice Shop.

\section{Introduction}

Wikipedia (2013) defined competition is the rivalry among sellers trying to achieve such goals as increasing profits, market share, and sales volume by varying the elements of the marketing mix such as price, product, distribution, and promotion. In this globalised arena, business firms toil hard for to respond to business competition. Responding to business competition needs to know factors determining competition or rivalry. Kadamb (2013) stated that the marketing environment surrounds and impacts upon the organization. Marketing experts cascades three key perspectives of the marketing environment such as macroenvironment, micro-environment and internal environment. Of which, micro environment includes suppliers that deal directly or indirectly, customers and other local stakeholders. Porter (1980) designed a model called Porter's five forces model using micro environmental forces. Porter's five forces model is made up by identification of 5 fundamental competitive forces such as barriers to entry, threat of substitutes, bargaining power of buyers, bargaining power of suppliers and rivalry among the existing players. Rivalry is determined by all other four factors such as barriers to entry, threat of substitutes, bargaining power of buyers and bargaining power of suppliers. Rivalry is found almost in every business. On that basis, rivalry is inevitable among rice selling business. According to Department of Agricultre (2013), rice is the preferred staple food in Sri Lanka and different varieties are produced to suit local requirements. Approximately 60 percent of consumption is made up of long grain white rice. Approximately 30 percent of consumption is made up of short grain white rice. Approximately 10 percent of consumption is parboiled red rice and other local varieties. A small portion consists of imported basmati rice varieties from India and Pakistan. Assuming a population of 21 million people, Sri Lanka's annual per capita rice consumption is close to $100 \mathrm{Kgs}$. Rice shops are the intermediaries for selling rice to consumers for consumption. Competition is unavoidable today's ever changing and complex business 
environment. Rice shop businessmen and entrepreneurs are facing the problems of competitors' rivalry. Therefore, rice shops try hard to sustain their business by maintaining competitive advantage over the other rice shops.

\section{Statement of the problem}

Researcher conducted a discussion with 20 rice shop owners. Of them, 5 owners indicated that emerging new rice shops are emerging and threatening them. Another 5 rice shop owners indicated that rice producers (rice suppliers) are bargaining more with them. Another 5 rice shop owners stated that there are substitute door to door rice sellers who are the threat for them. The remaining 5 rice shop owners quoted that rice buyers are bargaining with them. These statements are contradictory from one another. But, all are contributing to rivalry in industry. Porter (1980) found that there is relationship between threats of new entry, power of suppliers, threats of substitutes \& power of buyer and competitive rivalry. Numbers of previous related studies confirm that rivalry is determined by customer, supplier, new entrant and substitutes. Specifically speaking, Porter (1991); Miller and Dess (1993); Porter (1980); and (1994); , and (2008); Ferrier and Lee (2002); Ramaswamy (2001); (1999) studied about competitors' rivalry and factors affecting competitive rivalry. This idea has been also highlighted by studies. Porter (1980) stated that five forces model is a very elaborate concept for evaluating company's competitive position. This model is often used in strategic planning and probably one of the most commonly used business strategy tools. Department of Agriculture (2013) stated that the current policy of the Government of Sri Lanka (GoSL) intends maintaining self-sufficiency in rice production and consumption. The GoSL guarantees a minimum price to farmers via the Paddy Marketing Board and, in addition, also maintains a maximum retail price for consumers. It could be stated that when self- sufficiency is created rice will be supplied to enough level and be available to consumers in all rice shops. There would be competition among rice shops for maintaining existing customers and attracting new customer. According to Department of Agriculture (2013), the GoSL further subsidizes up to 95 percent of the cost of fertilizer and provides irrigation water free-of-charge through the country's reservoir system. Farmers are required to grow only rice on paddy lands. This will further increase the production of paddy that would be later sold via rice shops for the final consumption. This will still strengthen the competition among rice shops. These dilemmas would create owners of rice shops for knowing what factors results in competitive rivalry among them. Each and every rice shop owner has to have insight and knowledge about competition among existing rice shops in the industry.

\section{Research question and objectives}

Discussion among rice shop owners, empirical evidences and figures \& Statistics of Department of Agriculture (2013) revealed that research problem exist on competitive rivalry among rice shop owners. Based on these, this study attempts to raise the following two research questions. They are: what factors determine the competitive rivalry? and whether factors affecting competitive rivalry are related with competitive rivalry?. The above research questions are translated into research objectives. They are: to determine factors affecting the competitive rivalry and to know the relationship among factors affecting competitive rivalry and competitive rivalry

\section{Motivations of this study}

This study motivated researcher for various reasons. First, competitive rivalry is determined by four forces in Porter's model that is used as a strategic business tool. Business manager are in need of seeking factors affecting competitive rivalry. Second, this study is useful to determine the competitive advantage over the competitors. 
Competitive rivalry determines the direction of one business where the business will develop an edge over rival firms. This study is useful to determine the industry context in which the firm operates and to analyze attractiveness of an industry structure. Third, knowing the factors determining competitive rivalry is useful for making investment decision. For example, Porter has simplified the construct of rivalry into measures that can easily be understood by all. Analyzing factors determining competitive rivalry is useful to develop a broad and sophisticated analysis of competitive position that can be then used when creating strategy, plans, or making investment decisions about your business or organization. Porter (1980) indicated that and his model has proven its usefulness in numerous situations. It describes the relationship between firms and the driving forces that control this relationship. It is a more local relationship and the firm may exercise a degree of influence. It is one of the strategic tools used by business managers. Fourth, this study might improve paddy production. Rice shop owners can get feedback from consumers that can be submitted with paddy producers who in turn produce to meet the needs and wants of consumers. Fifth, this study can promote to reduce rice imports from other countries. Department of Agriculture (2013) indicated that paddy rice production in Sri Lanka for 2011/2012 recorded an all time high of 4.869 million metric tons. Record rice production has boosted consumption and rice stocks as well as helped the country become a surplus producer. When South Eastern Region of Sri Lanka gets self- sufficiency in paddy production rice imports might be are discouraged in Sri Lanka. Or else, imports might be limited to small quantities of specialties such as Basmati. Sixth, this study might help to save foreign exchanges when reducing rice imports. About 20,000 metric tons per year has been the total import quantity for 2010, 2011 and estimated for 2012 and 2013. In 2011, Sri Lanka donated 7500 metric tons of rice to the World Food Program highlighting a shift from a rice deficit nation to that of a rice surplus nation.

\section{Previous studies}

Ismail (2010) studied about product mix and sales maximization of rice mill entrepreneurs in Ampara Coastal Area, Eastern Province of Sri Lanka. This study was conducted among rice mill entrepreneurs. This was from the perspective of marketing and entrepreneurship. This was adopted a survey study. Porter (1991) reviewed the progress of the strategy field towards developing a truly dynamic theory of strategy. This study then reviewed three promising streams of research that address the longitudinal problem. These still fall short of exposing the true origins of competitive success. This study expresses that there are still shortage for knowing and clearly determining the factors for competitive success. Previous studies tested the generalisation and accuracy of Porter's model. For example, Miller and Dess (1993) assessed Porter's (1980) model in terms of its generalisability, accuracy and simplicity. The Porter (1980) model of generic strategies is evaluated in terms of simplicity, accuracy (i.e., predictive and explanatory power), and generalizability, through an empirical analysis. Results lead to one of the conclusions i.e. Porter's framework could be improved and strategies described by Porter are possibly more contingent than generic. Huff and Robinson (1994) studied about the impact of lead time and years of competitive rivalry on pioneer market share advantages. Research has established that for surviving brands, market pioneers have a higher average market share than later entrants. Increasing the years of competitive rivalry should help a later entrant slowly deduct the pioneer's market share advantage. Hema and Anura (2008) studied about resource management in dyadic competitive rivalry in relation to the effects of resource bundling and deployment. 


\section{Constructs and Measures}

This study follows a research concepts and measures developed by Porter (1980). This same is adopted by researcher in this study. Adopting Porter (1980), this study considers bargaining power of suppliers that is measured by moderate number of suppliers, supplier is large, similar products, able to substitute and neutral supplier power; bargaining power of buyer that is measured by few large players, very large orders, homogenous product, extreme price sensitivity, ability to substitute and high buyer power. Threats of new entrant is measured by not too expensive to enter into the industry, experience needed but training is easily available, some economies of scale, some cost benefits is in business for sometimes, no technology protection, low barriers to entry and new entry is quiet easy. Threats of substitutes are measured by some cross product substitution, ability to import substitutes and some substitution. Competitive rivalry is measured by many competitors, commodity products, low switching costs and high cost of leaving market.

\section{Research Methodology}

\section{Population and sample}

Population size of rice shop owners is not clear so far. There are no proper records about rice shop owners. So, researcher could not select a sample size in this study using probability sampling method. This study uses a non-probability sampling method for sample selection. Considering this situation, researcher selected 127 rice shop owners using a convenient sampling technique.

\section{Data collection}

Data were collected using questionnaire. Questionnaires were scaled on a five point-likert scale. Data were collected during 2013 using undergraduates of Faculty of Management and Commerce, South Eastern University of Sri Lanka. 200 questionnaires were delivered for data collection. 127 questionnaires were in usable status. Response rate was around 64\%.

\section{Data analysis}

Factor analysis (Principal Component Analysis) was conducted using SPSS with collected data.

\section{Results and discussion of findings}

\section{Reliability}

Cronbach alpha is most widely used method for checking the reliability of scale. It may be mentioned that its value varies from 0 to 1 but, satisfactory value is required to be more than 0.6 for the scale to be reliable (Ismail and Velnampy, 2013a \& b); Malhorta, 2002; Cronbach, 1951). In this study, researcher use Cronbach alpha scale as a measure of reliability. Threats of new entry have 7 items such not too expensive to enter into the industry, experience needed but training is easily available, some economies of scale, some cost benefits is in business for sometimes, no technology protection, low barriers to entry and new entry is quiet easy. Power of suppliers has 5 items such as moderate number of suppliers, supplier is large, similar products, able to substitute and neutral supplier power. Threats of substitutes have 3 items such as some cross product substitution, ability to import substitutes and some substitution. Power of buyer has 6 items such as few large players, very large orders, homogenous product, extreme price sensitivity, ability to substitute and high buyer power. Competitive rivalry has 4 items such as very many competitors, commodity products, low switching costs and high cost of leaving market. Values of Cronbach alpha are $0.874, \quad 0.789, \quad 0.654, \quad 0.865$ and 0.783 respectively.

\section{Communalities and testing the sufficiency of sample size}

Researcher tested collected data for
appropriateness for factor analysis. Appropriateness of factor analysis is dependent upon the sample size. In this connection, MacCallum, Windaman, Zhang and Hong (1999) have advocated that if all communalities are above 0.6 relatively small samples (less than 
100) may be perfectly appropriate. Ismail and Velnampy (2013a) studied about determinents of employee satisfaction in public health service organizations in eastern province of Sri Lanka. Ismail and Velnampy (2013b) studied about determinents of corporate performance in public health service organizations in eastern province of Sri Lanka. In these studies, authors considered a sample of 100 employees. This present study also adopts this same rule. Items of threats of new entry $(0.998,0.946,0.960,0.929,0.998$, $0.946 \& 0.846)$, power of suppliers $(0.947$, $0.863,0.856,0.874 \& 0.944)$, threats of substitutes $(0.922 \&$ \& 0.922$)$, power of buyer $(0.935,0.918,0.922,0.923,0.820 \& 0.822)$, competitive rivalry $(0.963,0.965,0.963 \& 0.963)$ are all greater than 0.6 which shows that sample size is enough to run factor analysis.

\section{Keyzer-Meyer-Oklin (KMO) and Bartlet's test of sphericity}

Measure of Keyzer-Meyer-Oklin (KMO) is another method for to show the appropriateness of data for factor analysis. KMO statistics varies between 0 and 1. Keyzer (1974) recommended that values greater than 0.5 are acceptable; between 0.5 to 0.7 are moderate; between 0.7 to 0.8 are good; between 0.8 to 0.9 are superior (Field, 2000). Bartlet's test of sphericity is the final statistical test applied in this study for verifying its appropriateness (Bartlet, 1950). In this study, values of KMO for items of threats of new entry, power of suppliers, threats of substitutes, power of buyer, competitive rivalry are $0.771,0.653 \& 0.500,0.777 \& 0.531$ respectively. These values indicate sample taken to process factor analysis is statistically significant. In addition to $\mathrm{KMO}$, Chi- square values for these factors are 1171.3, 473.884,
155.696, $725.563 \& 492.501$ respectively. These values confirm test is statistically significant when significance value is less than significance level. Significance value is 0.000 at $5 \%$ level of significance. These values indicate that data are statistically significant for factor analysis.

\section{Factor analysis}

After examining the reliability of the scale and test appropriateness of data as above, researchers carry out factor analysis to determine factors affecting competitive rivalry of rice shop owners and to find out the relationship between competitive rivalry and factors affecting competitive rivalry of rice shop owners. For achieving these objectives, researcher employs principal component analysis (PCA) that is followed by the varimax rotation. Varimax rotation is mostly used in factor analysis (Hema and Anura, 1993). In this study, threats of new entry and power of suppliers have a couple of components. Threats of substitutes have a single component. Powers of buyer and competitive rivalry have also a couple of components. These factors explain around 95\%, 90\% \& 92\%, 89\% $\& 96 \%$ of the total variation respectively.

\section{Regression analysis}

\section{Strength of association}

Value of $\mathrm{R}, \mathrm{R}$ square and adjusted $\mathrm{R}$ square is $0.953,0.908$ and 0.905 respectively. There is a high strength of association between threats of new entry, power of suppliers, threats of substitutes, power of buyer and competitive rivalry of rice shop owners. Their signs are positive. This means when threats of new entry, power of suppliers, threats of substitutes \& power of buyer go up competitive rivalry

Table 1: Model Summary

\begin{tabular}{|l|r|r|r|r|}
\hline Model & $\mathrm{R}$ & R Square & Adjusted R Square & \multicolumn{1}{c|}{$\begin{array}{c}\text { Std. Error of the } \\
\text { Estimate }\end{array}$} \\
\hline 1 & .953 & .908 & .905 & .71139 \\
\hline
\end{tabular}

a. Predictors: (Constant), Buyerpowercomponent12, Threatsofnewentrantcomponent12, Supplierpowercomponent12, Threatsofsubstitutescomponent 11 
also goes up. Model summary is shown in Table 1.

\section{Sum of Squares and Mean Sum of Squares}

SS Total is the total variation in competitive rivalry explained by both threats of new entry, power of suppliers, threats of substitutes \& power of buyer go up and other variables. Value of SS Total is 674.450. SS Total is the sum of SS Regression and SS Residual. Degrees of freedom is refered by Df. Df regression is 4 refers to that there are 4 independent variables such as threats of new entry, power of suppliers, threats of substitutes \& power of buyer in this model. Df residual is obtained by $127-1-1$ equals 122 . Df Total 126. Mean Square regression is the mean variation explained by threats of new entry, power of suppliers, threats of substitutes \& power of buyer. Value of MS Rreg is 153.177. Mean Square residual or error is the mean variation explained by other variables. Value of MS Reg is 0.506 .

\section{F statistics and hypothesis testing}

Researcher develops both null and alternatives.

1. Null hypothesis: There is no relationship between threats of new entry, power of suppliers, threats of substitutes \& power of buyer and competitive rivalry.

2. Alternative hypothesis: There is relationship between threats of new entry, power of suppliers, threats of substitutes $\&$ power of buyer and competitive rivalry.

F statistics is the ratio between MS regression divided by MS residual. Value of F statistics is 302.675. Sig. value refers to that probability of $\mathrm{TS}_{\mathrm{CAL}}$ falls in critical region is 0.000 . It means that $\mathrm{TS}_{\mathrm{CAL}}$ have no chance to fall in the critical region. This means there are much more chance to fall in the acceptance region. So, researcher rejects null and accepts alternative. Accepting alternative hypothesis means there is relationship between threats of new entry, power of suppliers, threats of substitutes \& power of buyer and competitive rivalry. Related statistics are shown in ANOVA Table 2.

Table 2: ANOVA

\begin{tabular}{|rl|r|r|r|r|r|}
\hline \multicolumn{2}{|l|}{ Model } & Sum of Squares & Df & Mean Square & F & Sig. \\
\hline 1 & Regression & 612.709 & 4 & 153.177 & 302.675 & $.000^{\mathrm{a}}$ \\
& Residual & 61.742 & 122 & .506 & & \\
& Total & 674.450 & 126 & & & \\
\hline
\end{tabular}

a. Predictors: (Constant), Buyerpowercomponent12, Threatsofnewentrantcomponent12, Supplierpowercomponent12,

Threatsofsubstitutescomponent1 1

b. Dependent Variable: Competitiverivalrycomponent12 


\section{Estimated or predicted value formula}

$\mathrm{B}$ is referred to as non- standardized regression coefficient. In this study, non- standardized beta coefficient for threats of new entrant, supplier power, threats of substitutes and buyer power are $0.000,0.307,-0.615$ and 0.866 respectively. a s referred to as constant. Value of a is -.046. Estimated or predicted value of Yi(competitive rivalry) is calculated by the following formulae. $\mathrm{Yi}=-.046+.000$ threats of new entrant +0.307 supplier power $+(-0.615)$ threats of substitutes + 0.866 buyer power. When threats of new entry, power of suppliers, threats of substitutes and power of buyer increase by one unit competitive rivalry remains unchanged, rises by 0.307 , falls by 0.866 and rises by 0.866 .

\section{T statistics and hypotheses}

$\mathrm{T}$ statistics is used to test relationship between threats of new entry, power of suppliers, threats of substitutes \& power of buyer and competitive rivalry. $\mathrm{T}$ statistics is derived when $\mathrm{b}$ is divided by $\mathrm{SEb}$. Values of $\mathrm{T}$ statistics for threats of new entry, power of suppliers, threats of substitutes \& power of buyer are $-.008,4.789,-9.811 \& 15.434$ respectively.
1. Null hypotheses: There are no relationships between threats of new entry, power of suppliers, threats of substitutes \& power of buyer and competitive rivalry.

2. Alternative hypotheses: There are relationships between threats of new entry, power of suppliers, threats of substitutes $\&$ power of buyer and competitive rivalry.

Sig. values refer to the probability of $\mathrm{TS}_{\mathrm{CAL}}$ falling in critical region are $0.993,0.000,0.000$ $\& 0.000$. It refers to that $\mathrm{TSs}_{\mathrm{CAL}}$ have no chance to fall in the critical region. This means there are much more chances to fall in the acceptance region. So, accepts null ad rejects alternative for threats of new entry and competitive rivalry. So, threats of new entry are not related with competitive rivalry. Vice versa, researcher rejects null and accepts alternatives for power of suppliers, threats of substitutes \& power of buyer and competitive rivalry. Power of suppliers, threats of substitutes and power of buyer are related with competitive rivalry. Related statistics are shown in coefficient Table 3.

Table 3: Coefficients ${ }^{\mathrm{a}}$

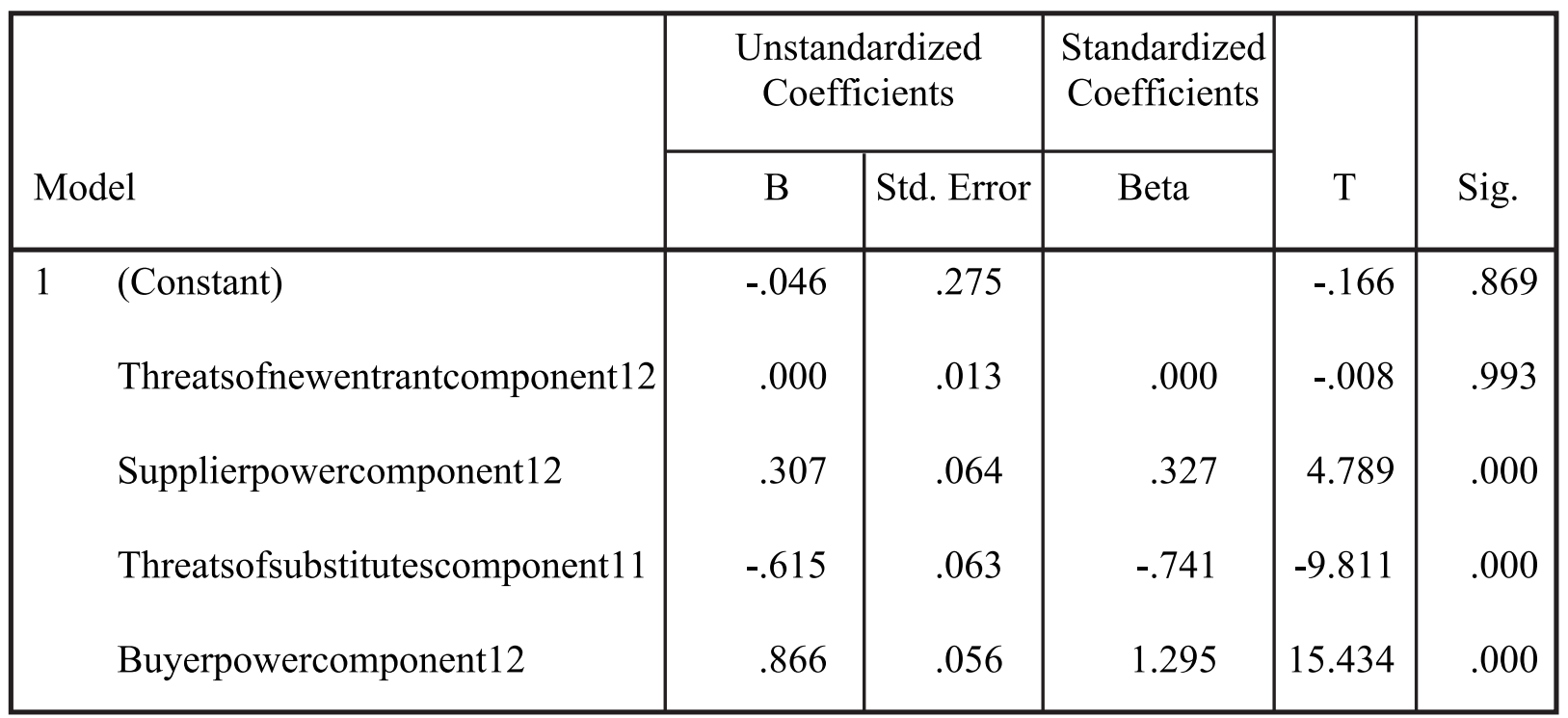

a. Dependent Variable: Competitiverivalrycomponent 12 


\section{Conclusions}

Results showed that values of Cronbach alpha for items of threats of new entry, power of supplier, threats of substitutes, power of buyer and competitive rivalry are $0.874,0.789,0.654$, 0.865 and 0.783 respectively. This shows that items used in this study have high reliability. Communalities for all items range between 0.820 to 0.988 which are greater than 0.6 . This shows that there is sufficient sample size. Values of KMO for items of threats of new entry, power of suppliers, threats of substitutes, power of buyer, competitive rivalry are $0.771,0.653 \& 0.500$, $0.777 \& 0.531$ respectively. These values indicate sample taken to process factor analysis is statistically significant. Conclusion revealed that threats of new entry and power of suppliers that have a couple of components, threats of substitutes that has a single component \& powers of buyer and competitive rivalry that have also a couple of components explain around $95 \%, 90 \% \& 92 \%, 89 \% \& 96 \%$ of the total variation respectively. Since value of $\mathrm{R}, \mathrm{R}$ square and adjusted $\mathrm{R}$ square is $0.953,0.908$ and 0.905 respectively there is a high strength of association between threats of new entry, power of suppliers, threats of substitutes, power of buyer and competitive rivalry of rice shop owners. Value of F statistics is 302.675. Sig. value refers to that probability of $\mathrm{TS}_{\mathrm{CAL}}$ falls in critical region is 0.000 . This means there is relationship between threats of new entry, power of suppliers, threats of substitutes $\&$ power of buyer and competitive rivalry. Estimated or predicted value of $\mathrm{Yi}$ (competitive rivalry) is: $\mathrm{Yi}$ $=-.046+.000$ threats of new entrant +0.307 supplier power $+(-0.615)$ threats of substitutes + 0.866 buyer power. When threats of new entry, power of suppliers, threats of substitutes and power of buyer increase by one unit competitive rivalry remains unchanged, rises by 0.307 , falls by 0.866 and rises by 0.866 . Values of $\mathrm{T}$ statistics for threats of new entry, power of suppliers, threats of substitutes \& power of buyer are $-.008,4.789,-9.811 \& 15.434$ respectively. Sig. values refer to the probability of $\mathrm{TS}_{\mathrm{CAL}}$ falling in critical region are $0.993,0.000,0.000$ $\& 0.000$. Threats of new entry are not related with competitive rivalry. Power of suppliers, threats of substitutes and power of buyer are related with competitive rivalry.

\section{Scope for future research}

Methodologically, sample size has not been taken into account using sample size formulae. So, research can be conducted to eliminate this limitation. There are many home based, womenbased and door to door rice sellers who were not into account in this study. Future researches could be carried out removing deficiencies of these.

\section{References}

Argyres, N. and McGahan, A. M. (2002), "An interview with Michael Porter" Academic Management Perspective, Vol. 16, No. 2, pp. 43-52

Bartlet, M. S. (1950), "Test of significance in factor analysis", British Journal of statistical psychology, Vol. 3, pp. 77- 85

Cronbach, L. J. (1951), "Coefficient Alpha and the Internet Structure of the Tests, Psychometrika", Vol. 6, No. 3, pp. 297-334.

Department of Agriculture (2013), "Rice", Paddy rice production. Retrieved from http://www.agridept.gov.lk/index.php/en/croprecommendations $/ 808$. Accessed on: 22/ 10/ 2013.

Ferrier, W. J. and Lee, H. (2002), "Competitive rivalry", Journal of Managerial Issues, Vol. 14, No. pp. 162-180.

Field, A. (2000), "Discovering statistics using SPSS for windows", London, Sage Publication

Kadamb, A. (2013), "How to Prepare a Marketing Environmental Analysis “, Retrieved from http:// marketingteacher.com/lessonstore/lesson-marketing-environment.html. Retrieved on 19- Aug, 2013. 
Hema, W. and Anura, D. Z. (1993), "A factor analytical study of the determinants of success in Manufacturing SMEs", School of Accounting and Finance, University of Wollongong, Australia. Retrieved August, 28. 2008. Accessed from: http://www.app.lese.edu.au.

Huff, L. C. and Robinson, W. T. (1994), "The impact of lead time and years of competitive rivalry on pioneer market share advantages, Management Science, Vol. 40 No. 10, pp. $1370-1377$

Ismail, M.B.M. (2010), "Product Mix and Sales Maximization of Rice Mill Entrepreneurs in Ampara Coastal Area, Eastern Province of Sri Lanka", Journal of Management, Vol. 6, Iss. 1, pp. 13-27.

Ismail, M.B.M. and Velnampy, T. (2013), "Determinants of Employee Satisfaction (ES) in Public Health Service Organizations (PHSO) in Eastern Province of Sri Lanka: A Pilot Study", European Journal of Business and Management, Vol. 5, Iss. 21, pp. 62-71

Ismail, M.B.M. and Velnampy, T. (2013), "Determinants of Corporate Performance (CP) in Public Health Service Organizations (PHSO) in Eastern Province of Sri Lanka: A Use of Balanced Score Card (BSC)", Industrial Engineering Letters, Vol. 3, Iss. 8, pp. 1-9.

Kaizer, H. F. (1974), "An Index of factorial simplicity", Psychometrica, Vol. 39, pp. 31-36

Koh, H.C. (1996), "Testing hypotheses of entrepreneurial characteristics: A study of Hong Kong MBA students", Journal of Managerial Psychology, Vol. 11, Iss: 3, pp.12-25

MacCallum, R. C., Windaman, K. F., Zhang, S. and Hong, S. (1999), "Sample size factor analysis", Psychological Methods, Vol. 4, pp. 84-99

Malhorta, N. K. (2006), "Marketing Research: An Applied Orientation", $3^{\text {rd }}$ edition, New Delhi, India, Pearson Education Asia.

Miller, A. and Dess, G. G. (1993), "Assessing Porter's (1980) model in terms of its generalisability, accuracy and simplicity", Journal of Management Studies, Vol. 30, pp. 553-585.

Porter, M. E. (1979), "How Competitive Forces Shape Strategy", Harvard Business Review, Free Press, U.S.A.

Porter, M. E. (1980), "The five competitive forces that shape strategy", Harvard Business Review, Free Press, U.S.A.

Porter, M. E. (1991), "Towards a dynamic theory of strategy", Strategic Management Journal, Vol. 12, pp. 95-117.

Ramaswamy, K. (2001), “Organizational ownership, competitive intensity, and firm performance: an empirical study of the Indian manufacturing sector", Strategic Management Journal, Vol. 22, Iss. 10, pp. 989-998.

Shepherd, D. A. (1999), "Venture Capitalists' Assessment of New Venture Survival", Management Science, Vol. 45, No. 5, pp. 621-632

Sirmon, D. G., Gove, S. and Hitt, M. A. (2008), "Resource management in dyadic competitive rivalry in relation to the effects of resource bundling and deployment", Academic Management Journal, Vol. 51, No. 5, pp. 919-935

Stephenson, J. (2013), "25 common characteristics of successful entrepreneurs", Accessed from: http;//www.entrepreneur.com/article/200730 . Accessed: October 21, 2013.

Wikipedia (2013), "business competition", Web definitions, Accessed from http://en.wikipedia.org/wiki/Business_competiti on. Accessed on: 10/ 22/ 2013. 